\title{
An analytical approach for extraction and detection of permethrin from functionalized textile materials
}

\author{
DOI: $10.35530 / 1 T .070 .02 .1600$
}

\author{
ELENA PERDUM \\ DOINA TOMA \\ MARIANA VAMESU \\ ELENA-CORNELIA MITRAN
}

\author{
IRINA MARIANA SANDULACHE \\ DANA-GEORGETA CIUTARU \\ LUCIA OANA SECAREANU \\ OVIDIU-GEORGE IORDACHE
}

\section{REZUMAT - ABSTRACT}

\section{O abordare analitică privind extracția și detectarea permetrinului din materialele textile funcționalizate}

Odată cu dezvoltarea industriei textile și a tehnologiei, interesul pentru crearea de textile cu valoare adăugată este în continuă crestere. Tendința globală este de a functionaliza materialele textile în scopuri precise și bine definite. Materialele textile fac din ce în ce mai mult obiectul standardelor de înaltă calitate, iar funcționalizarea acestora trebuie să fie foarte eficientă și cu un impact minim asupra mediului și sănătății umane. Scopul acestei cercetări a fost de a determina conținutul de permetrin din tricoturile fabricate din fibre funcționale Cell Solution $®$, care asigură o protecție eficientă împotriva insectelor. Substanța Permetrin (conform recomandării OMS, $\mathrm{C}_{21} \mathrm{H}_{20} \mathrm{Cl}_{2} \mathrm{O}_{3}$, numărul CAS: 52645-53-1) este integrată în fibre. Permetrinul este o substanță care acționează similar cu piretrul natural extras din florile de crizantemă. Atunci când insectele intră în contact cu fibrele Cell Solution® PROTECTION, se activează efectul "knock-down" al substanței. Un stimul inițiat chimic determină insectele să rămână pe materialele textile o perioadă mai scurtă de timp, reducând astfel riscul de mușcături dureroase și cu potențial infectant. Efectul de respingere lucrează în special asupra căpușelor, acarienilor și țânțarilor. Acest studiu urmărește, de asemenea, să facă o comparație între efectul diferitelor metode de tricotat (cicluri repetate de spălare a materialelor textile, expunerea la lumina vizibilă a testelor de rezistență la intemperii) pentru a observa stabilitatea insecticidului încorporat în fibră. Pentru extracția permetrinului din tricoturi, a fost utilizată metoda inovativă de extracție accelerată cu solvent (ASE) și pentru cuantificarea substanței, a fost utilizată metoda cromatografiei de lichide cu detecție spectrofotometrică (HPLC-MWD). Atât cis-permetrinul, cât și trans-permetrinul au fost detectate în probe, iar pentru confirmarea izomerică au fost analizate și probele extrase pe gaz cromatografie (GC-MS).

Cuvinte cheie: permetrin, fibre Cell Solution® PROTECTION, cromatografie de lichide, extracție accelerată cu solvent, textile functionalizate

\section{An analytical approach for extraction and detection of permethrin from functionalized textile materials}

With the development of textile industry and technology, the interest in creating value-added textiles is growing more and more. The global trend is to functionalize textile materials for narrow and well-defined purposes. Textile materials are increasingly subject of high quality standards and their functionalization must be very efficient and with minimal impact on the environment and human health. The purpose of this research was to determine the content of permethrin from knits made of Cell Solution $®$ functional fibers, which provide effective protection against insects. The substance permethrin (according to WHO recommendation, $\mathrm{C}_{21} \mathrm{H}_{20} \mathrm{Cl}_{2} \mathrm{O}_{3}, \mathrm{CAS}$ number: 52645-53-1) is integrated into the fibers. Permethrin is a substance that acts similar to the natural pyrethrum extracted from chrysanthemum flowers. When insects get into contact with Cell Solution ${ }^{\circledR}$ PROTECTION fibers, the knockdown effect of the substance sets in. A chemically initiated stimulus causes insects to stay on the textile shorter thus reducing the risk of painful and infectious bites or strings. The repellent effect is particularly working on ticks, mites and gnats. This research also aims to make a comparison between the effect of different knitting methods (repeated washing cycles of textile materials, exposure to Weather Fastness Tester-visible light) in order to observe the stability of the insecticide incorporated into the fiber. For the extraction of permethrin from knits we used the innovative method of accelerated solvent extraction method (ASE) and for the quantification of the substance we used the liquid chromatographic method with spectrophotometric detection (HPLC-MWD). Both cis-permethrin and trans-permethrin were found in the samples, and for isomeric confirmation we analysed the extracted samples also on gas chromatography (GC-MS).

Keywords: permethrin, Cell Solution ${ }^{\circledR}$ PROTECTION Fibers, liquid chromatography, accelerated solvent extraction, functionalized textiles

\section{INTRODUCTION}

Permethrin is a synthetic repellent compound applied to textile materials in order to prevent tick attachment and to decrease mosquito populations. It bonds to textiles in same way as colorants and it is safe for all types of fabrics [1].

The chemical structure of permethrin [figure 1] is related to a naturally insecticide obtained from petals of dried chrysanthemum cinerariifolium. Permethrin consists in a mixture of $(+)$ cis-Permethrin and $(+)$ trans-Permethrin, in either a 40:60 or 25:75 ratio [2]. Permethrin was the first pyrethroid insecticide produced and has strong and rapid repellency effect. The US military uses it for protection of the personnel [3]. There are also medicinal products that contain permethrin, therefore various studies were conducted 


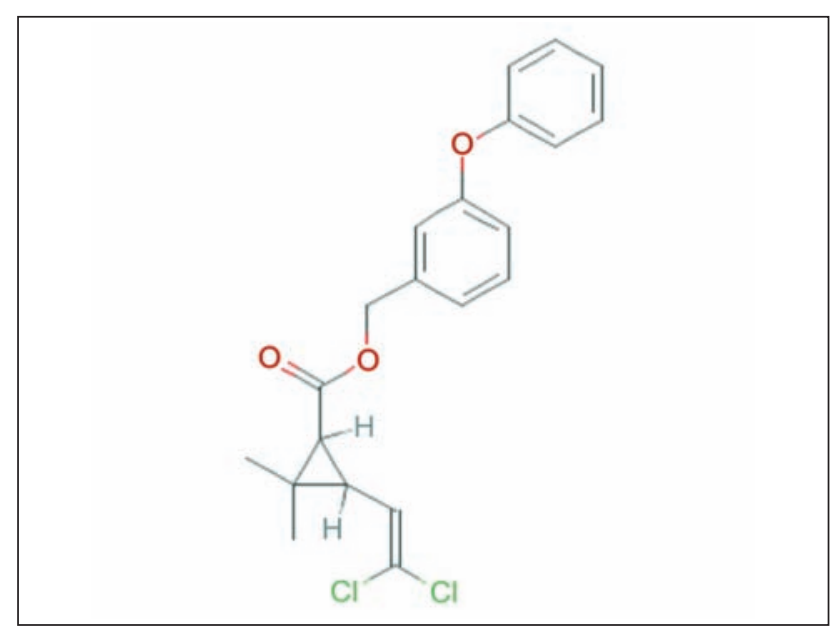

Fig. 1. Chemical structure of permethrin [IUPAC name: 3-phenoxyphenyl) methyl 3-(2,2-dichloroethenyl)-2,2dimethylcyclopropane-1-carboxylate] [6]

not only for permethrin testing but also of its metabolites.

In spite of being effective against all stages of insect growth, permethrin is one of the least toxic insecticides to humans and the only one registered by the US Environmental Protection Agency (EPA) for use on clothing and in agricultural and pharmaceutical applications in the United States $[4,5]$.

Due to the diversity of the products containing permethrin and their complex matrices, the development of the testing procedures relies on the hydrophobicbonding tendency of the substance. Therefore, the partition coefficient of permethrin was determined in order to be available for area of interests (pharmaceutical, toxicology, ecology, etc.) [7].

For permethrin analysis are reported several methods based on separation techniques followed by identification and quantification using different types of detectors (GC-FID [8], GC-ECD [9], GC-MS [10], HPLC-DAD [11], HPLC-UV [12-13]. The challenging in permethrin testing is to establish the suitable HPLC chromatographic conditions that ensure complete resolution of the two geometric isomers.

Cell Solution ${ }^{\circledR}$ Protection is a natural cellulose fiber with embedded permethrin inside the fibers. This design provides releasing of an amount of permethrin to the surface at each washing cycle and, consequently it ensures the protection capability in time. Additionally, Cell Solution ${ }^{\circledR}$ Protection fibers shows a strong PCM effect and is therefore capable of storing and releasing large amounts of heat. The Protection fiber can cool (store heat) or warm (release heat) when needed thus giving some extra comfort and relief to the user.

\section{EXPERIMENTAL}

In our experiments, we used a Cell Solution Protection knit, functionalized with insecticide permethrin; firstly we extracted and determined the amount of permethrin in the raw knit, than in the same raw sample which was subjected to laundering ( 25 washing cycles). Afterwards, we evaluated the degradation of insecticide by exposing the raw knit to Xenotest visible light for 50 hours and for 100 hours, using Apollo Xenon Arc Light and Weather Fastness Tester 700 James Heal, in the following conditions:

\section{Exposure condition}

- artificial light: xenon lamp;

- the temperature of the black standard: $47 \pm 3^{\circ} \mathrm{C}$;

- effective humidity: approx. $40 \%$;

- irradiance: $\pm 2 \mathrm{~W} / \mathrm{m}^{2}$ for wavelengths between 300 and $400 \mathrm{~nm}$.

All the four test specimens were afterwards subjected to accelerated solvent extraction. Approximately $1 \mathrm{~g}$ of material was weighed out of each sample. Then, the samples were cut into pieces and introduced into extraction cells which were filled with diatomaceous earth and subjected to methanolaccelerated extraction.

\section{Extraction method}

The extraction was performed using an Accelerated Solvent extraction system (Dionex-Thermo Scientific) with $22 \mathrm{ml}$ Extraction cells (stainless steel).

The conditions of the extraction method are the following:

Solvent: Methanol;

Heating time: $5 \mathrm{~min}$;

Static time: $100 \mathrm{~min}$;

Extraction cycles: 3 ;

Temperature: $80^{\circ} \mathrm{C}$;

Washing: $60 \%$ with methanol.

\section{Reagents and standards}

- Permethrin (CAS 52645-53-1; e.g. PESTANAL);

- Acetonitrile and methanol gradient grade from Merck KGaA (Germany);

- Water for chromatography (resistivity min. 18.2 $\mathrm{MW} \times \mathrm{S} \times \mathrm{cm}, \mathrm{TOC}$ max. $50 \mathrm{ppb}$ ).

After extraction, the resulting solutions were allowed to cool and subsequently filtered through $0.45 \mu \mathrm{m}$ PTFE filters and transferred to vials for further analysis by HPLC-MWD. In order to quantify the amount of permethrin in the textile samples a 5-points calibration curve was made by diluting stock solution of permethrin in methanol (3000 ppm, mg/L) to the following concentrations: 2400 ppm, 1800 ppm, 1200 ppm, $600 \mathrm{ppm}$ and $300 \mathrm{ppm}$. The calibration curve of cispermethrin is presented in figure 2 , and the calibration curve for trans-permethrin is presented in figure 3 .

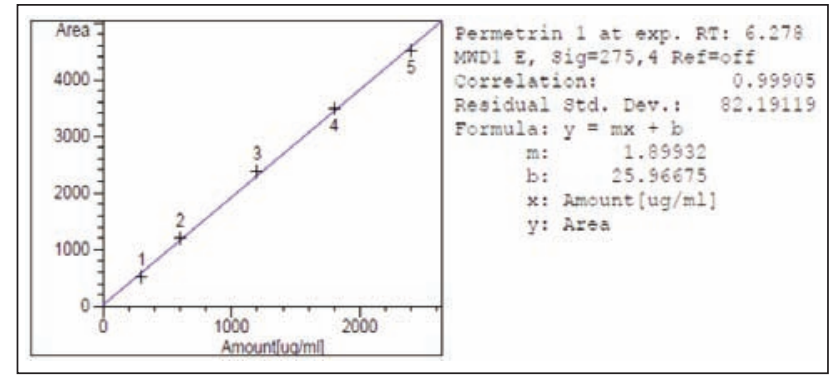

Fig. 2. 5-points calibration curve for cis-permethrin 


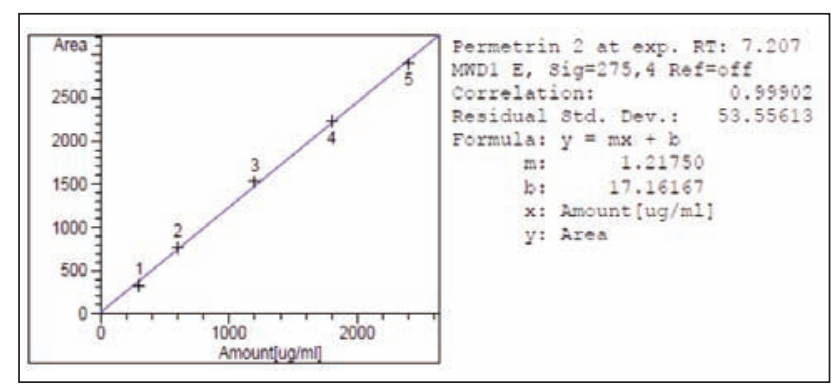

Fig. 3. 5-points calibration curve for trans-permethrin

\section{Chromatographic detection}

HPLC separation was performed on Agilent 1100 LC System using an Agilent Zorbax Eclipse XDB C18 column and MWD detector (table 1).

Table 1

\begin{tabular}{|l|l|}
\hline \multicolumn{2}{|l|}{ AGILENT $1100 \mathrm{HPLC}$ MWD OPERATING CONDITIONS } \\
\hline Analytical Column & $\begin{array}{l}\text { Zorbax Eclipse XDB C18 } \\
150 \mathrm{~mm} \times 4.6 \mathrm{~mm} \times 3.5 \mu \mathrm{m}\end{array}$ \\
\hline Column Temp. & $32^{\circ} \mathrm{C}$ \\
\hline Injection Volume & $10.0 \mu \mathrm{l}$ \\
\hline Mobile Phase & $\begin{array}{l}\text { Eluent: Acetonitrile/Water: } 90 / 10, \\
\text { isocratic }\end{array}$ \\
\hline Run time & $15 \mathrm{~min}$ \\
\hline Flow rate & $0.8 \mathrm{~mL} / \mathrm{min}$ (isocratic) \\
\hline Quantification & at 202 and $275 \mathrm{~nm}$ \\
\hline
\end{tabular}

Table 2

\begin{tabular}{|c|c|}
\hline \multicolumn{2}{|c|}{$\begin{array}{c}\text { GC-MS 6890N / } 5793 \text { AGILENT TECHNOLOGIES } \\
\text { OPERATING CONDITIONS }\end{array}$} \\
\hline Capillary column & $\begin{array}{l}\text { DB-35MS }(\mathrm{J} \& \mathrm{~W}) \circledast \text {, length: } 35 \mathrm{~m} \text {, } \\
\text { inside diameter } 0.25 \mathrm{~mm}\end{array}$ \\
\hline Injection system & $\begin{array}{l}\text { splitless; Injector temperature: } \\
250^{\circ} \mathrm{C}\end{array}$ \\
\hline Carrier gas & helium \\
\hline Flow rate & $1.24 \mathrm{~mL} / \mathrm{min}$ \\
\hline Temp. program & $\begin{array}{l}\text { Initial temp.: } 70^{\circ} \mathrm{C}(1 \mathrm{~min}), \text { Heating } \\
\text { rate: } 25^{\circ} \mathrm{C} / \mathrm{min} ., \text { Final temp.: } 280^{\circ} \mathrm{C} \\
(8 \mathrm{~min}) ;\end{array}$ \\
\hline Injection volume & $1 \mu \mathrm{l}$ \\
\hline Detector & MS (mass spectrometer) \\
\hline
\end{tabular}

Isomeric confirmation of cis and trans-permethrin was performed on GC-MS 6890N/5793 Agilent Technologies, with cappilary column (table 2).

\section{RESULTS AND DISCUSSION}

As we can see in table 3 , washing the knit determined an important loss of quantity of permethrin,

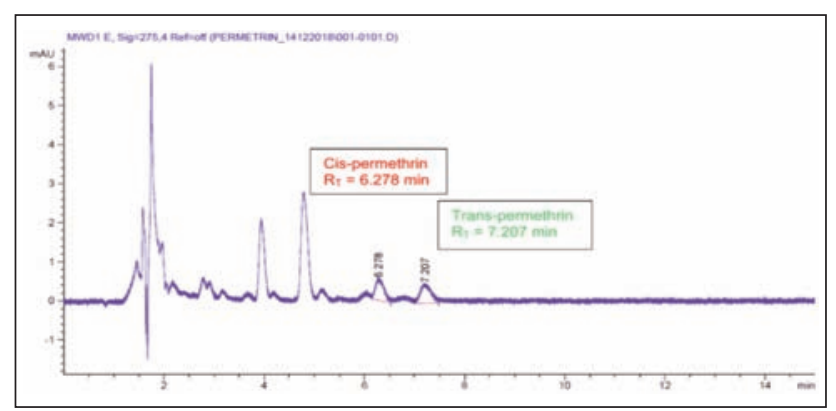

Fig. 4. HPLC Chromatogram of washed (25 cycles) raw Cell Solution Protection knit

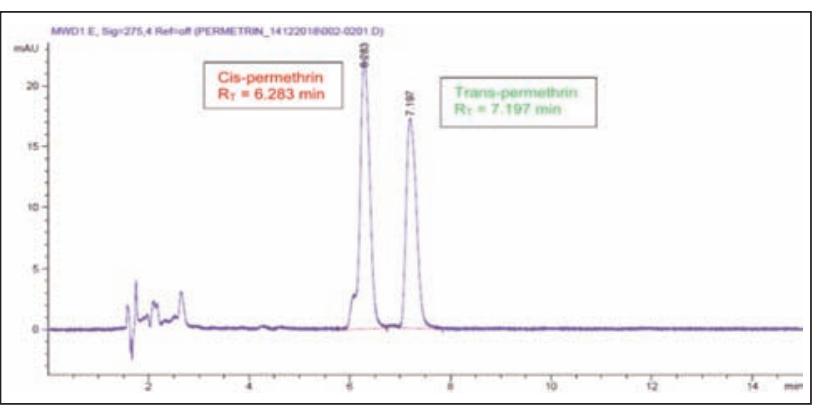

Fig. 5. HPLC Chromatogram of washed (25 cycles) raw Cell Solution Protection knit after $50 \mathrm{~h}$ of Xenon arc lamp exposure

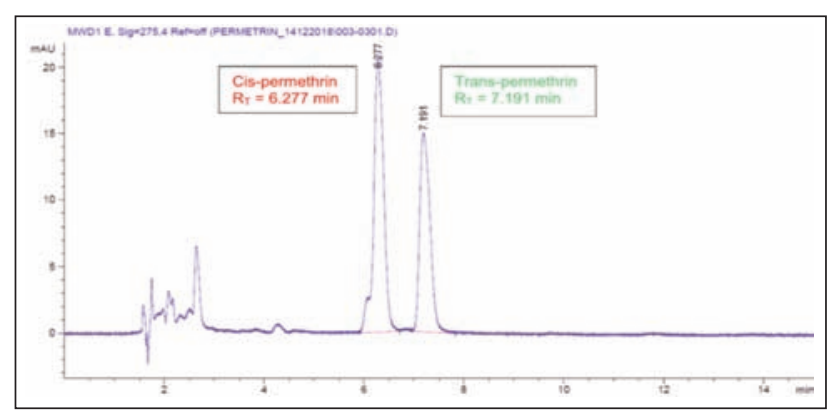

Fig. 6. HPLC Chromatogram of washed (25 cycles) raw Cell Solution Protection knit after $100 \mathrm{~h}$ of Xenon arc lamp exposure

QUANTIFICATION OF CIS-PERMETHRIN AND TRANS-PERMETHRIN

\begin{tabular}{|l|c|c|}
\hline \multicolumn{2}{|c|}{ QUANTIFICATION OF CIS-PERMETHRIN AND TRANS-PERMETHRIN } \\
\hline \multicolumn{1}{|c|}{ Sample } & $\begin{array}{c}\text { Amount of cis-permethrin } \\
{[\mathbf{m g} / \mathbf{k g}]}\end{array}$ & $\begin{array}{c}\text { Amount of trans-permethrin } \\
{[\mathrm{mg} / \mathrm{kg}]}\end{array}$ \\
\hline Raw Cell Solution Protection knit & 267.45 & 328.23 \\
\hline $\begin{array}{l}\text { Washed (25 cycles) raw Cell Solution Protection } \\
\text { knit }\end{array}$ & $<$ LOD & $<$ LOD \\
\hline $\begin{array}{l}\text { Washed (25 cycles) raw Cell Solution Protection } \\
\text { knit after 50 } \mathrm{h} \text { Xenotest exposure }\end{array}$ & 166.43 & 210.75 \\
\hline $\begin{array}{l}\text { Washed (25 cycles) raw Cell Solution Protection } \\
\text { knit after 100 } \mathrm{h} \text { Xenotest exposure }\end{array}$ & 158.42 & 187.22 \\
\hline
\end{tabular}




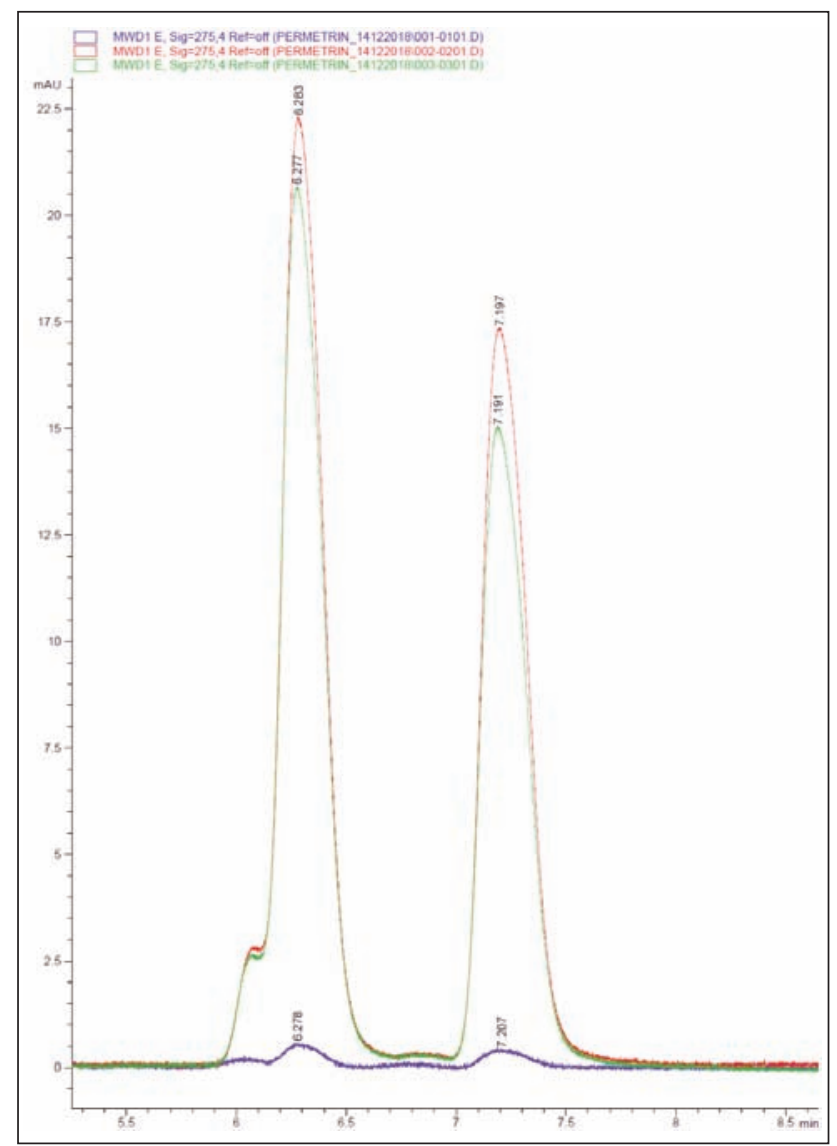

Fig. 7. Overlaid HPLC chromatograms of washed (25 cycles) raw Cell Solution Protection knit (blue), knit after $50 \mathrm{~h}$ of Xenotest exposure (red) and knit after $100 \mathrm{~h}$ of Xenotest exposure (green) thus the amount of insecticide being below limit of detection of the method. Basically, knit laundering determined a significant decrease of extractable permethrin. The quantity of cis and trans-permethrin decreases also after Xenotest exposure, but less compared to laundering, probably due to the fact that visible light affects the molecular integrity of permethrin, causing the degradation of this chemical substance. Also, the quantity of cis and trans-permethrin decreased with the increasing of exposure time.

\section{CONCLUSION}

In this study, both cis-permethrin and trans-permethrin have been extracted and detected in textile samples. The highest quantity of permethrin was found in raw sample. On the other side, the lowest quantity of permethrin was found in washed knit, demonstrating insecticide instability in the knit after repeated washing cycles. Knit exposure to xenon arc lamp determined important loss of insecticide, correlated with the hours of exposure, demonstrating a slight molecular instability of permethrin to prolonged exposure to visible light.

\section{ACKNOWLEDGEMENTS}

This project is funded by the Ministry of Research and Innovation within Program 1 - Development of the national RD system, Subprogram 1.2 - Institutional Performance RDI excellence funding projects, Contract no 6PFE/ 16.10.2018and project number PN-III-P2-2.1-PTE-20160041, within PNCDI III.

\section{BIBLIOGRAPHY}

[1] Tessier, D. "Surface modification of biotextiles for medicinal applications", Biotextile as Medical Implants, 2013; https://www.sciencedirect.com/topics/chemistry/permethrin.

[2] https://monographs.iarc.fr/wp-content/uploads/2018/06/mono53-13.pdf.

[3] Hayes, D. G. "Functional Textiles for Improved Performance", Protection and Health, 2011.

[4] Hebeish, A., Hamdy, I. A., El-Sawy, S. M., Abdel-Mohdy, F. A. Preparation of durable insect repellent cotton fabric through treatment with a finishing formulation containing cypermethrin, In: J. Text. Inst., 101 (2010), pp. 627-634.

[5] Abdel-Mohdy, F.A., Gaballa, M.M., Fawzy, M., Sayed, A. Repellency of controlled-release treated-cotton fabrics based on permethrin and bioallethrin against mosquitoes, In: J. Text. Inst., 100 (8) (2009), pp. 695-701

[6] https://pubchem.ncbi.nlm.nih.gov/compound/Permethrin\#section=Top

[7] Rao, T. N., Srinivasarao, T., Botsa, P. A simple reverse phase HPLC method for determination of partition coefficient of permethrin pesticide, In: CHAIJ, 2016, 1 (1), pp. 1-5.

[8] Amin, M.A., El-Degwy, M.A., Fayed, B.A. Determination of permethrin in pharmaceutical product by gas chromatography, In: IOSR- J. Pharm. and Biol. Sci, 2017, Volume 12, Issue 6, Ver. VI (Nov.-Dec.), pp. 42-45.

[9] Pakvilai, N., Prapamontol, T., Thavornyutikam, P., Mangklabruks, A., Chantara, S., Honsibsong, S., Santasup C. A simple and sensitive GC-ECD method for detecting synthetic pyrethroid insecticide residues in vegetable and fruit samples, In: Chiang Mai J. Sci. 2015; 42 (1), pp. 196-207.

[10] Lestremau, F., Willemin, M.E., Chatellier, C., Desmots, S., Brochot, C. "Determination of cis- pemethrin, transpermethrin and associated metabolites in rat blood and organs by gas chromatography-ion trap mass spectrometry, In: Analytical and Bioanalytical Chemistry, Springer Verlag, 2014, 406 (14), pp. 3477-3487.

[11] Shishovska, M. A., Stefova M.T. Fast and universal HPLC method for determination of permethrin in formulations using 1.8- $\mu$ m particle-packed column and performance comparison with other column types, In: J. Chromatogr. Sci., 2012, Jan; 50(1), pp. 43-50. 
[12] Stefova, M.T., Shishovska, M.A., Trajkovska, V.P. A simple HPLC method for determination of permethrin residues in wine, In: J. Environ. Sci He alth B., 2010, Oct, 45(7), pp. 694-701.

[13] Garcia, E., Garcia, A., Barbas, C. Validated HPLC method for quantifying permethrin in pharmaceutical formulation, In: J. Pharm. Biomed. Analysis, 2001, March, Volume 24, Issues 5-6, pp. 999-1004.

\section{Authors:}

ELENA PERDUM, DOINA TOMA, MARIANA VAMESU, ELENA-CORNELIA MITRAN, IRINA MARIANA SANDULACHE, DANA-GEORGETA CIUTARU, LUCIA OANA SECAREANU, OVIDIU-GEORGE IORDACHE

National R\&D Institute for Textiles and Leather Bucharest (INCDTP)

16 Lucretiu Patrascanu, 030508 Bucharest, Romania

e-mail: certex@certex.ro, webpage: http://www.certex.ro

Corresponding author:

ELENA PERDUM

e-mail: elena.varzaru@certex.ro 